\title{
ANALISIS EFEKTIVITAS PAJAK DAERAH, RETRIBUSI DAERAH, HASIL KEKAYAAN DAERAH YANG DIPISAHKAN DAN LAIN-LAIN PENDAPATAN ASLI DAERAH YANG SAH SERTA KONTRIBUSINYA TERHADAP PENDAPATAN ASLI DAERAH KABUPATEN/KOTA DI PROVINSI ACEH
}

\author{
Raudhatinur* $^{* 1}$, Endang Surasetyo Ningsih ${ }^{* 2}$ \\ ${ }^{1,2}$ Program Studi Akuntansi Fakultas Ekonomi dan Bisnis Universitas Syiah Kuala \\ e-mail: raudhatinur26@gmail.com ${ }^{* 1}$,endangsnt@ unsyiah.ac.id $^{* 2}$
}

\begin{abstract}
The purpose of this research isto analyze the effectiveness of local taxes, local retribution, Local own source assets and others Legitimate local revenue and its contribution to the local revenue of districts/ cities in Aceh Province. The method in this research is using descriptive quantitative methods, with effectiveness analisys and contribution analisys as the instrument of the analisys. The result of this research shows that the average of the effectiveness in period (2013-2017) of the Local Tax is89,91\% (quite effective), local retribution is 77,87\% (less effective),Local own source assetsis 107,06 \% (very effective), and others Legitimate local revenueis 102,06\% (very effective. The average of the contribution in period (2013-2017) of local taxes is 15,15\% (less), local retribution is 20,46\% (medium), Local own source assets is 4,89\% (very less), and others Legitimate local revenue is 50,46\% (very good)
\end{abstract}

Keywords: local taxes, local retribution, Local own source assets and others Legitimate local revenue

\section{Pendahuluan}

Undang-undang No. 23 Tahun 2014 menyatakan bahwa pemerintah daerah diberi hak, kewenangan dan kekuasaan berupa otonomi daerah untuk mengatur dan mengurus sendiri kepentingan daerahnya masing-masing dengan tujuan untuk mensejahterakan masyarakat. Tujuannya diharapkan mampu memberikan kesejahteraan dengan cepat kepada masyarakat melalui peningkatan pelayanan, pemberdayaan, keadilan suatu daerah. Dalam penerapan desentralisasi fiskal di Indonesia, pemerintah pusat memberikan kewajiban untuk mengatur dan mengelola sendiri segala urusan pemerintahan termasuk dalam pengelolaan keuangan daerah agar mengelola sumber pendanaan daerah tersebut secara efektif (Abdullah dan Nazry, 2014). Menurut UU No. 23 Tahun 2014 Pasal 280 menyebutkan salah satu sumber pendanaan dalam pelaksanaan otonomi adalah PAD (Pendapatan Asli Daerah). UU No. 23 Tahun 2014 Tentang Pemerintah Daerah pasal 1 ayat ke-35 menyebutkan bahwa pendapatan asli daerah adalah semua hak daerah yang diakui sebagai penambah nilai kekayaan bersih dalam periode tahun anggaran yang bersangkutan. Komponen PAD tersebut antara lain pajak daerah, retribusi daerah, hasil kekayaan daerah yang dipisahkan da lain-lain pendapatan asli daerah yang sah. Berdasarkan Qanun Aceh No. 11 Tahun 2017 Aceh merupakan salah satu daerah otomomi di Indonesia yang memiliki keistimewaan untuk mengatur dan mengurus sendiri kepentingan masyarakatnya. Akan tetapi, PAD Provinsi Aceh belum terealisasi dengan baik. PAD yang dikatakan baik jika jumlah realisasi penerimaannya lebih besar daripada jumlah target yang ditentukan. Hal tersebut dapat dilihat berdasarkan data yang diambil langsung oleh peneliti dari DPKA (Dinas Pengelola Keuangan Aceh) dimana jumlah realisasi penerimaan PAD untuk daerah Aceh di tahun 2017 masih relatif sangat rendah jika dibandingkan dengan target yang dibuat oleh pemerintah setiap daerah. Berikut adalah tabel realisasi dan target PAD tahun 2017. 


\section{Tabel 1}

Pendapatan Asli Daerah

\begin{tabular}{|l|c|c|c|}
\hline Kabupaten/Kota & Target PAD (2017) & Realisasi PAD (2017) & $\begin{array}{c}\text { Persen } \\
\mathbf{( \% )}\end{array}$ \\
\hline Kabupaten Aceh Barat Daya & $102.620 .488 .662,00$ & $91.571 .494 .831,20$ & $89,23 \%$ \\
\hline Kota Sabang & $48.885 .657 .700,00$ & $55.081 .057 .066,02$ & $112,67 \%$ \\
\hline Kota Banda Aceh & $280.877 .031 .733,00$ & $270.170 .805 .366,00$ & $96,19 \%$ \\
\hline Kabupaten Aceh Besar & $126.380 .380 .300,00$ & $145.464 .468 .479,16$ & $115,1 \%$ \\
\hline Kabupaten Pidie & $354.941 .845 .159,00$ & $267.608 .101 .034,43$ & $75,39 \%$ \\
\hline Kabupaten Pidie Jaya & $53.022 .268 .723,00$ & $47.409 .466 .484,99$ & $89,41 \%$ \\
\hline Kabupaten Bener Meriah & $117.489 .110 .244,00$ & $82.038 .407 .023,70$ & $69,83 \%$ \\
\hline Kabupaten Aceh Tengah & $174.466 .831 .381,00$ & $163.000 .739 .413,09$ & $93,43 \%$ \\
\hline Kota Bireun & $210.797 .958 .883,00$ & $192.939 .858 .236,27$ & $91,53 \%$ \\
\hline Kota Lhokseumawe & $64.251 .583 .646,00$ & $62.986 .260 .103,85$ & $98,03 \%$ \\
\hline Kabupaten Aceh Utara & $255.272 .144 .071,00$ & $202.091 .566 .054,51$ & $79,17 \%$ \\
\hline Kabupaten Aceh Timur & $164.288 .180 .444,00$ & $158.492 .371 .449,82$ & $96,47 \%$ \\
\hline Kota Langsa & $127.325 .504 .605,00$ & $120.138 .956 .032,87$ & $94,36 \%$ \\
\hline Kabupaten Aceh Tamiang & $147.425 .735 .124,00$ & $116.246 .212 .753,70$ & $78,85 \%$ \\
\hline Kabupaten Aceh Jaya & $62.425 .121 .489,99$ & $52.599 .500 .273,85$ & $84,26 \%$ \\
\hline Kabupaten Aceh Barat & $185.972 .324 .490,00$ & $161.742 .858 .643,95$ & $86,97 \%$ \\
\hline Kabupaten Nagan Raya & $116.121 .893 .442,49$ & $74.051 .054 .126,89$ & $63,77 \%$ \\
\hline Kabupaten Aceh Selatan & $150.819 .203 .027,32$ & $140.875 .267 .831,74$ & $93,41 \%$ \\
\hline Kota Subulussalam & $70.328 .774 .557,52$ & $56.519 .514 .115,17$ & $80,36 \%$ \\
\hline Kabupaten Aceh Singkil & $58.180 .463 .317,00$ & $43.441 .129 .848,31$ & $74,67 \%$ \\
\hline Kabupaten Simeulue & $58.968 .896 .639,00$ & $61.095 .183 .851,33$ & $103,61 \%$ \\
\hline Kabupaten Gayo Lues & $64.388 .474 .577,60$ & $60.312 .455 .602,47$ & $93,67 \%$ \\
\hline Kabupaten Aceh Tenggara & $115.755 .171 .495,00$ & $60.053 .234 .222,18$ & $51,88 \%$ \\
\hline & & & \\
\hline
\end{tabular}

\section{Laporan Realisasi Anggaran 2017}

Data diatas menggambarkan bahwa masih banyak Kabupaten/Kota di provinsi Aceh yang perbandingan target penerimaan PAD dengan realisasinya jauh berbanding terbalik. Hal tersebut mengindikasikan bahwa 21 Kabupaten/Kota di Provinsi Aceh belum dapat mengoptimalkan pendapatan asli daerahnya dengan baik, karena hanya Kota Sabang dan Kabupaten Aceh Besar yang mampu mengoptimalkan realisasi penerimaan PAD daerahnya lebih besar dari pada target PAD. Upaya peningkatan PAD dapat dilakukan oleh pemerintah daerah dengan memaksimalkan penerimaan yang bersumber dari empat komponen PAD yaitu pajak daerah, retribusi daerah, hasil kekayaan daerah yang dipisahkan dan lain-lain PAD yang sah. Menurut Suhono dan Sulastri (2017) Pemaksimalan sumber komponen PAD tersebut dilakukan dengan cara meningkatkan efektivitas pemungutan yaitu salah satunya dengan mengoptimalkan potensi yang ada pada masingmasing daerah tersebut kemudian selanjutnya Pemerintah juga dapat menggali sumber-sumber pendapatan baru yang potensinya memungkinkan sehingga dapat menambah penerimaan sumber komponen PAD. Penelitian terkait dengan efektivitas dan kotribusi pajak daerah dan retribusi daerah terhadap PAD sudah pernah dilakukan oleh Octovido dan Azizah (2014) di Kota Batu, hasil penelitian tersebut menunjukkan bahwa pada tahun 2012 tingkat efektifitas tertinggi pajak daerah sebesar $(136,67 \%)$ dan terendah pada tahun 2010 sebesar $(69,30 \%)$, serta untuk kontribusi pajak daerah tertinggi pada tahun 2012 yakni sebesar $(72,66 \%)$ dan terkecil pada tahun 2009 sebesar $(45,21 \%)$. 
Adapun penelitian diatas hanya meneliti pajak daerah dan retribusi daerah saja, akan tetapi terdapat 2 komponen lainnya dari PAD yaitu hasil kekayaan daerah yang dipisahkan dan lain-lain PAD yang sah juga memiliki peranan penting pada penerimaan PAD. Menurut Handoko (2013) untuk mengoptimalkan penerimaan PAD harus ditingkatkan keempat komponennya yakni pajak daerah, retribusi daerah, hasil kekayaan daerah yang dipisahkan dan lain-lain PAD yang, maka dari itu peneliti menambahkan 2 komponen PAD untuk menghitung efektifitas dan kontribusinya guna melihat secara keseluruhan penerimaan PAD untuk kabupaten/kota di Provinsi Aceh.

\section{Kerangka Teoritis \\ Pendapatan Asli Daerah}

Menurut Halim (2004:94) PAD adalah penerimaan yang diperoleh daerah dari sumber-sumber dalam wilayahnya sendiri yang dipungut berdasarkan peraturan daerah sesuai dengan peraturan perundangundangan yang berlaku. Sumber pendapatan asli daerah. PAD (Pendapatan Asli Daerah) merupakan pendapatan daerah yang bersumber dari hasil pajak daerah, hasil retribusi Daerah, basil pengelolaan kekayaan daerah yang dipisahkan, dan lain-lain pendapatan asli daerah yang sah, yang bertujuan untuk memberikan keleluasaan kepada daerah dalam menggali pendanaan dalam pelaksanaan otonomi daerah sebagai mewujudan asas desentralisasi. Pendapatan asli daerah adalah salah satu sumber dana pembiayaan pembangunan daerah pada kenyataannya belum cukup memberikan sumbangan bagi pertumbuhan daerah, hal ini mengharuskan pemerintah daerah menggali dan meningkatkan pendapatan daerah terutama sumber pendapatan asli daerah.

\section{Pajak Daerah}

Menurut Suhono dan Sulastri (2017) pajak dearah merupakan iuran wajib kepada wajib pajak yang bersifat memaksa untuk kepentingan daerah. Sedangkan menurut Setiawan dan Surtini (2017) Pajak daerah merupakan salah satu komponen PAD yang dikenakan kepada masyarakat oleh pemerintah yang bersifat memaksa yang hasilnya akan digunakan untuk membiayai keperluan daerah.

Jenis pajak dan tarif pajak diatur dalam UU No. 28 Tahun 2009 tentang pajak daerah dan retribusi daerah. Jenis pajak disebutkan dalam pasal 2 yaitu pajak provinsi dan pajak kabupaten/kota. Pajak provinsi dijabarkan dalam pasal 1 terdiri atas: Pajak Kendaraan Bermotor, Pajak Bea Balik Nama Kendaraan Bermotor, Pajak Bahan Bakar Kendaraan Bermotor, Pajak Air Permukaan, dan Pajak Rokok. Pajak kabupaten/kota sama halnya dijelaskan dalam pasal 1 UU No. 28 Tahun 2009 tentang pajak daerah dan retribusi daerah yang terdiri atas: Pajak Hotel, Pajak Restoran, Pajak Hiburan, Pajak Reklame, Pajak Penerangan Jalan, Pajak Mineral Bukan Logam, Pajak Parkir, Pajak Air Tanah, Pajak Sarang Burung Walet, PBB Kota dan Desa dan Pajak BPHTB.

\section{Retribusi Daerah}

Menurut UU No. 28 Tahun 2009 pasal 1 ayat 64 tentang pajak daerah dan retribusi daerah menyebutkan bahwa retribusi daerah adalah pungutan Daerah sebagai pembayaran atas jasa atau pemberian izin tertentu yang khusus disediakan dan/atau diberikan oleh Pemerintah Daerah untuk kepentingan orang pribadi atau Badan. Retribusi daerah merupakan salah satu sumber penerimaan yang dapat dipungut terus menerus mengingat pengeluaran pemerintah daerah adalah untuk anggaran rutin dan anggaran pembangunan selalu meningkat (Asnariza dan Hamzah, 2014).

Menurut Sayangbati et all. (2016) retribusi daerah merupakan komponen penting sebagai sumber Pendapatan Asli Daerah yakni atas pemberian izin yang disediakan Pemerintah untuk kepentingan badan atau pribadi. Sesuai dengan UU No.28 Tahun 2009 tentang Pajak Daerah dan Retribusi Daerah dalam pasal 108 dinyatakan bahwa terdapat Objek Retribusi Daerah yaitu: Jasa Umum, Jasa Usaha, dan Perizinan Tertentu.

\section{Hasil Kekayaan Daerah yang Dipisahkan}

UU No. 23 Tahun 2014 pasal 285 ayat (1) menjelaskan bahwa Hasil Pengelolaan Kekayaan Daerah Yang Dipisahkan antara lain bagian laba dari BUMD dan hasil kerja sama dengan pihak ketiga. Hasil Kekayaan Yang dipisahkan ini ditetapakan dengan Perda dengan tetap berpedoman pada peraturan peundang-undangan. Objek dari Hasil pengelolaan kekayaan daerah menurut UU Nomor 23 Tahun 2014 dirincikan sebagai berikut : (1) bagian laba atas penyertaan modal pada perusahaan milik 
daerah/BUMD, (2) bagian laba atas penyertaan modal pada perusahaan milik pemerintah/BUMN, dan (3) bagian laba atas penyertaan modal pada perusahaan milik swasta atau kelompok usaha masyarakat.

\section{Lain-lain Pendapatan Asli Daerah yang Sah}

Lain-lain Pendapatan Asli Daerah Yang Sah dijelaskan juga dalam UU No 23 Tahun 2014 bahwa yang dimaksud dengan lain-lain pendapatan asli Daerah yang sah antara lain penerimaan Daerah di luar pajak daerah dan retribusi daerah seperti jasa giro dan hasil penjualan aset Daerah.

Menurut Devas (1989) dalam Abdullah (2016) adapun jenis penerimaan dari lain-lain PAD yang sah yaitu jenis penerimaan lain-lain daerah yang mencakup penerimaan kecil seperti hasil penjualan alat berat dan bahan jasa, penerimaan dari sewa, bunga simpanan giro dan bank serta penerimaan dari denda kontraktor.

\section{Efektivitas}

UU Nomor 23 Tahun 2014 Pasal 262 menjelaskan efektivitas adalah kemampuan mencapai target dengan sumber daya yang dimiliki dengan cara atau proses yang paling optimal. Halim (2008:234) menjelaskan pengukuran dari efektivitas dapat dilihat dari ukuran timbal balik antara target dan realisasi, artinya semakin besar tingkat realisasi penerimaannya maka semakin efektif pula suatu program yang dilakukan oleh unit organisasi tersebut. Sehingga dari pengertian tersebut dapat dirumuskan pnegukuran efektivitas sebagai berikut:

$$
\text { Efektivitas }=\frac{\text { Realisasi Penerimaan }}{\text { Target Penerimaan }} \times 100 \%
$$

\section{Kontribusi}

Menurut Isfatul, et all. (2014) kontribusi merupakan sesuatu yang diberikan untuk suatu kegiatan agar dapat memberikan dampak untuk dirasakan. Kontribusi dapat menggambarkan seberapa besar tingkat penerimaan masing-masing komponen Pendapatan Asli Daerah setiap tahunnya. Tingkat kontribusi dari komponen PAD (Pajak Daerah, Retribusi Daerah, Hasil Pengelolaan Kekayaan Daerah Yang Dipisahkan Dan Pendapatan Asli Daerah Yang Sah) dapat dilakukan dengan membandingkan realisasi penerimaan komponen PAD periode tertentu dengan realisasi penerimaan Pendapatan Asli Daerah periode tertentu (Handoko, 2013).

\section{Metode Penelitian Desain penelitian}

Jenis penelitian ini merupakan penelitian kuantitatif dengan tujuan studi adalah studi deskriptif (descriptive study). Dalam penelitian ini dilakukan untuk mengetahui dan menjelaskan tingkat efektifitas dan kontribusi penerimaan masing-masing komponen dari Pendapatan Asli Daerah di Provinsi Aceh. Tingkat intervensi dalam penelitian ini adalah intervensi minimal. Situasi studi pada penelitian ini adalah situasi tidak diatur (noncontrived setting) yaitu penelitian dapat dilakukan dalam lingkungan yang alami serta Unit analisis dalam penelitian ini adalah organisasi yaitu Pemerintah Kabupaten/Kota di Provinsi Aceh. Penelitian ini menggunakan data LRA (Laporan Realisasi Anggaran) Tahun 2013-2017.

\section{Populasi dan Sampel Penelitian}

Populasi pada penelitian ini adalah seluruh Kabupaten/Kota di seluruh Aceh terdiri dari 18 Kabupaten dan 5 Kota (otda.kemendagri.go.id). Sementara sampel pada penelitian dipilih adalah menggunakan Non Probability Sampling dengan metode sensus, yaitu teknik penentuan sample diambil keseluruhan dari populasi penelitian ( Sugiyono, 2017: 61).

\section{Sumber dan Teknik Pengumpulan Data}

Sumber data yang digunakan dalam penelitian ini adalah data sekunder. Data sekunder dalam penelitian ini berupa data LRA (Laporan Realisasi Anggaran) yang diperoleh dari DPKA (Dinas Pengelola Keuangan Aceh).

Teknik pengumpulan data dalam penelitian ini melalui dokumentasi yaitu dengan mengumpulkan data yang diperoleh langsung dari Dinas Pengelolaan Keuangan Aceh (DPKA) dan juga yang diperoleh dari jurnal atau artikel akuntansi, Undang-undang atau Peraturan Pemerintah dan juga buku-buku yang berkaitan dengan masalah yang diteliti.

\section{Hasil Penelitian dan Pembahasan}

Penelitian ini bertujuan untuk menganalisis tingkat efektivitas dan kontribusi dari keempat komponen Pendapatan Asli Daerah yaitu pajak daerah, retribusi daerah, hasil kekayaan daerah yang dipisahkan dan lain-lain pendapatan asli daerah yang 
sah. Data yang digunakan dalam penelitian ini adalah data sekunder yaitu Laporan Realisasi Anggaran Kabupaten/Kota Provinsi Aceh tahun 2013-2017.

Untuk melihat seberapa besar tingkat efektivitas pajak daerah, retribusi daerah, hasil kekayaan daerah yang dipisahkan dan lain-lain pendapatan asli daerah yang sah maka perlu adanya perhitungan target dan realisasinya, begitupun untuk melihat kontribusi dari masing-masing komponen Pendapatan Asli Daerah tersebut yakni data realisasi dari Pendapatan Asli Daerah tiap Kabupaten/Kota di Aceh. Berikut dilampirkan beberapa data diatas:

\section{Tabel 2}

Target Pajak Daerah 2013-2017

\begin{tabular}{|l|l|l|l|l|l|}
\hline \multicolumn{1}{|c|}{ Kab/Kota } & \multicolumn{1}{c|}{$\mathbf{1 0 1 3}$} & \multicolumn{1}{c|}{$\mathbf{2 0 1 4}$} & \multicolumn{1}{c|}{$\mathbf{2 0 1 5}$} & \multicolumn{1}{c|}{$\mathbf{2 0 1 6}$} & \multicolumn{1}{c|}{$\mathbf{2 0 1 7}$} \\
\hline Aceh Barat & 8.703 .050 .000 & 10.781 .300 .000 & 16.219 .403 .616 & 29.276 .277 .309 & 27.694 .000 .000 \\
\hline Aceh Barat Daya & 5.870 .600 .000 & 6.870 .600 .000 & 5.000 .000 .000 & 8.000 .000 .000 & 5.500 .000 .000 \\
\hline Aceh Besar & 27.197 .950 .000 & 36.845 .000 .000 & 43.890 .000 .000 & 43.890 .000 .000 & 50.100 .022 .000 \\
\hline Aceh Jaya & 2.527 .500 .000 & 3.102 .500 .000 & 3.397 .500 .000 & 4.933 .840 .584 & 6.248 .067 .964 \\
\hline Aceh Singkil & 4.395 .941 .160 & 4.840 .000 .000 & 5.650 .000 .000 & 5.470 .000 .000 & 8.005 .000 .000 \\
\hline Simeulue & 2.145 .000 .000 & 2.400 .000 .000 & 2.500 .000 .000 & 2.600 .000 .000 & 4.646 .000 .000 \\
\hline Aceh Tamiang & 5.739 .354 .787 & 10.224 .154 .848 & 10.777 .730 .475 & 13.505 .330 .475 & 17.797 .253 .520 \\
\hline Aceh Tengah & 5.327 .794 .000 & 5.832 .794 .000 & 9.564 .894 .000 & 9.564 .894 .000 & 10.684 .794 .000 \\
\hline Aceh Tenggara & 4.227 .600 .000 & 6.279 .600 .000 & 5.870 .000 .000 & 8.555 .000 .000 & 11.765 .000 .000 \\
\hline Aceh Timur & 3.722 .000 .000 & 4.916 .000 .000 & 6.402 .000 .000 & 6.619 .500 .000 & 8.519 .000 .000 \\
\hline Aceh Utara & 14.396 .348 .000 & 22.043 .303 .000 & 21.361 .598 .774 & 23.984 .465 .846 & 24.786 .309 .000 \\
\hline Bener Meriah & 1.850 .374 .326 & 2.518 .450 .000 & 2.828 .450 .000 & 6.915 .000 .000 & 6.783 .079 .108 \\
\hline Bireun & 9.321 .215 .457 & 10.004 .215 .457 & 15.142 .984 .256 & 19.041 .768 .799 & 17.628 .788 .883 \\
\hline Gayo Lues & 1.664 .403 .464 & 1.853 .043 .464 & 2.395 .500 .000 & 5.017 .621 .212 & 3.891 .653 .932 \\
\hline Nagan Raya & 6.858 .825 .000 & 10.128 .000 .000 & 16.642 .502 .000 & 38.824 .500 .000 & 22.546 .369 .793 \\
\hline Pidie & 8.655 .725 .511 & 9.201 .933 .631 & 12.801 .933 .631 & 32.705 .722 .381 & 14.833 .722 .381 \\
\hline Aceh selatan & 5.357 .269 .350 & 6.071 .842 .491 & 8.978 .495 .000 & 15.105 .476 .870 & 12.793 .046 .000 \\
\hline Pidie Jaya & 4.804 .377 .832 & 5.204 .377 .832 & 5.204 .377 .832 & 5.340 .000 .000 & 5.320 .000 .000 \\
\hline Kota Banda Aceh & 36.460 .000 .000 & 42.135 .000 .000 & 47.635 .000 .000 & 53.085 .000 .000 & 61.095 .000 .000 \\
\hline Kota Langsa & 5.729 .914 .000 & 7.494 .319 .000 & 9.550 .000 .000 & 11.100 .000 .000 & 12.525 .000 .000 \\
\hline $\begin{array}{l}\text { Kota } \\
\text { Lhokseumawe }\end{array}$ & 15.421 .250 .000 & 20.326 .750 .000 & 26.943 .250 .000 & 23.984 .465 .846 & 28.623 .150 .951 \\
\hline Kota Sabang & 2.304 .893 .801 & 2.723 .769 .710 & 3.171 .177 .722 & 3.494 .896 .080 & 3.820 .213 .250 \\
\hline Kota Subussalam & 3.560 .000 .000 & 4.930 .000 .000 & 5.930 .000 .000 & 6.180 .000 .000 & 6.880 .000 .000 \\
\hline
\end{tabular}

Tabel 3

Realisasi Pajak Daerah 2013-2017

\begin{tabular}{|l|l|l|l|l|c|}
\hline \multicolumn{1}{|c|}{ Kab/Kota } & \multicolumn{1}{c|}{$\mathbf{1 0 1 3}$} & \multicolumn{1}{c|}{$\mathbf{2 0 1 4}$} & \multicolumn{1}{c|}{$\mathbf{2 0 1 5}$} & \multicolumn{1}{c|}{$\mathbf{2 0 1 6}$} & $\mathbf{2 0 1 7}$ \\
\hline Aceh Barat & 11.494 .461 .993 & 11.548 .102 .478 & 15.185 .097 .404 & 16.213 .699 .523 & 28.317 .437 .905 \\
\hline Aceh Barat Daya & 3.143 .272 .601 & 3.878 .188 .327 & 4.556 .358 .448 & 8.288 .329 .814 & 7.703 .596 .758 \\
\hline Aceh Besar & 41.104 .110 .553 & 52.520 .382 .605 & 53.284 .852 .783 & 53.284 .852 .784 & 62.041 .880 .230 \\
\hline Aceh Jaya & 3.237 .990 .571 & 8.439 .324 .173 & 3.592 .734 .291 & 4.285 .424 .510 & 7.046 .243 .726 \\
\hline Aceh Singkil & 4.567 .098 .199 & 3.778 .859 .419 & 4.253 .695 .051 & 4.738 .355 .197 & 6.919 .310 .656 \\
\hline Simeulue & 3.135 .619 .796 & 3.167 .599 .931 & 3.732 .470 .810 & 5.722 .429 .023 & 9.130 .843 .018 \\
\hline Aceh Tamiang & 9.921 .003 .473 & 8.358 .791 .910 & 8.369 .007 .319 & 8.643 .457 .946 & 11.230 .138 .884 \\
\hline Aceh Tengah & 5.929 .486 .657 & 6.685 .996 .921 & 9.838 .059 .366 & 11.465 .487 .062 & 11.022 .306 .411 \\
\hline Aceh Tenggara & 4.332 .464 .239 & 5.688 .082 .171 & 6.770 .678 .860 & 8.570 .250 .458 & 8.173 .569 .798 \\
\hline Aceh Timur & 4.371 .450 .662 & 7.129 .879 .239 & 8.031 .473 .347 & 8.308 .254 .260 & 10.457 .216 .638 \\
\hline Aceh Utara & 12.997 .494 .023 & 17.957 .243 .166 & 19.883 .019 .543 & 21.671 .743 .611 & 26.143 .329 .652 \\
\hline Bener Meriah & 1.883 .286 .090 & 2.621 .719 .142 & 3.263 .431 .159 & 5.173 .156 .853 & 5.537 .584 .592 \\
\hline Bireun & 9.404 .464 .634 & 11.983 .793 .632 & 17.648 .407 .313 & 16.536 .779 .057 & 19.705 .519 .346 \\
\hline
\end{tabular}




\begin{tabular}{|l|l|l|l|l|c|}
\hline \multicolumn{1}{|c|}{ Kab/Kota } & \multicolumn{1}{c|}{$\mathbf{2 0 1 3}$} & \multicolumn{1}{c|}{$\mathbf{2 0 1 4}$} & \multicolumn{1}{c|}{$\mathbf{2 0 1 5}$} & \multicolumn{1}{c|}{$\mathbf{2 0 1 6}$} & $\mathbf{2 0 1 7}$ \\
\hline Gayo Lues & 2.974 .996 .559 & 3.776 .538 .588 & 4.504 .078 .100 & 5.425 .604 .192 & 5.433 .785 .266 \\
\hline Nagan Raya & 5.866 .374 .609 & 11.012 .306 .021 & 13.960 .860 .229 & 19.833 .675 .569 & 19.480 .004 .604 \\
\hline Pidie & 11.614 .017 .585 & 13.225 .347 .430 & 15.071 .497 .073 & 35.966 .538 .764 & 18.184 .059 .300 \\
\hline Aceh selatan & 5.060 .404 .316 & 6.524 .722 .553 & 10.666 .653 .724 & 20.040 .049 .250 & 14.160 .145 .207 \\
\hline Pidie Jaya & 3.754 .327 .383 & 5.292 .528 .296 & 6.011 .691 .408 & 6.989 .747 .016 & 7.540 .980 .248 \\
\hline Kota Banda Aceh & 46.726 .398 .187 & 51.801 .124 .535 & 55.812 .362 .254 & 68.332 .671 .869 & 70.931 .534 .361 \\
\hline Kota Langsa & 6.109 .180 .218 & 9.400 .051 .991 & 10.090 .865 .225 & 10.855 .975 .158 & 13.293 .761 .533 \\
\hline $\begin{array}{l}\text { Kota } \\
\text { Lhokseumawe }\end{array}$ & 16.132 .259 .567 & 20.547 .131 .047 & 21.368 .637 .314 & 21.671 .743 .611 & 27.839 .764 .484 \\
\hline Kota Sabang & 2.886 .095 .491 & 4.458 .288 .579 & 5.168 .145 .598 & 4.851 .235 .221 & 5.771 .451 .908 \\
\hline Kota Subussalam & 2.631 .888 .781 & 3.787 .527 .962 & 4.235 .756 .539 & 4.332 .002 .553 & 5.674 .972 .218 \\
\hline
\end{tabular}

Tabel 4

Target Retribusi Daerah 2013-2017

\begin{tabular}{|l|c|c|c|c|c|}
\hline \multicolumn{1}{|c|}{ Kab/Kota } & $\mathbf{2 0 1 3}$ & $\mathbf{2 0 1 4}$ & $\mathbf{2 0 1 5}$ & $\mathbf{2 0 1 6}$ & $\mathbf{2 0 1 7}$ \\
\hline Aceh Barat & 24.605 .133 .284 & 84.315 .672 .134 & 17.125 .042 .976 & 10.370 .760 .624 & 9.315 .320 .584 \\
\hline Aceh Barat Daya & 13.220 .645 .200 & 9.050 .000 .000 & 4.840 .000 .000 & 4.116 .192 .000 & 4.340 .000 .000 \\
\hline Aceh Besar & 13.255 .287 .500 & 7.990 .300 .000 & 6.415 .300 .000 & 6.415 .300 .000 & 6.273 .705 .000 \\
\hline Aceh Jaya & 4.625 .930 .000 & 10.902 .273 .500 & 15.897 .578 .377 & 18.385 .759 .621 & 25.760 .202 .026 \\
\hline Aceh Singkil & 8.929 .348 .000 & 17.616 .260 .000 & 18.086 .070 .000 & 19.279 .396 .000 & 29.193 .575 .424 \\
\hline Simeulue & 10.395 .500 .000 & 2.017 .267 .128 & 2.046 .727 .128 & 1.937 .727 .128 & 2.065 .272 .872 \\
\hline Aceh Tamiang & 25.454 .622 .725 & 75.385 .034 .378 & 5.331 .632 .943 & 33.193 .881 .158 & 11.922 .753 .506 \\
\hline Aceh Tengah & 15.256 .092 .000 & 13.831 .041 .500 & 12.083 .030 .500 & 12.068 .030 .500 & 12.052 .882 .466 \\
\hline Aceh Tenggara & 20.623 .199 .062 & 34.005 .181 .000 & 29.824 .889 .500 & 33.078 .489 .500 & 38.708 .081 .500 \\
\hline Aceh Timur & 12.406 .264 .172 & 41.108 .030 .357 & 38.449 .213 .387 & 17.392 .826 .400 & 19.847 .489 .000 \\
\hline Aceh Utara & 66.893 .108 .982 & 130.681 .862 .553 & 46.904 .560 .599 & 5.089 .012 .952 & 3.610 .850 .000 \\
\hline Bener Meriah & 15.791 .243 .000 & 17.253 .511 .930 & 6.368 .550 .000 & 7.242 .200 .000 & 7.431 .350 .001 \\
\hline Bireun & 19.301 .526 .100 & 7.326 .968 .000 & 6.423 .370 .000 & 13.763 .141 .000 & 11.981 .370 .000 \\
\hline Gayo Lues & 12.195 .496 .979 & 19.422 .142 .000 & 19.029 .495 .500 & 18.984 .822 .369 & 26.731 .627 .901 \\
\hline Nagan Raya & 7.638 .500 .000 & 23.464 .698 .270 & 7.844 .996 .700 & 11.319 .996 .700 & 7.304 .996 .700 \\
\hline Pidie & 16.762 .244 .102 & 51.360 .771 .133 & 16.329 .582 .085 & 25.700 .690 .424 & 42.166 .782 .444 \\
\hline Aceh selatan & 23.729 .405 .000 & 9.112 .245 .412 & 5.237 .989 .000 & 3.283 .323 .331 & 7.447 .886 .343 \\
\hline Pidie Jaya & 13.950 .049 .200 & 23.162 .725 .119 & 28.895 .792 .972 & 28.760 .444 .381 & 27.448 .805 .926 \\
\hline Kota Banda Aceh & 17.515 .775 .000 & 23.285 .299 .646 & 24.310 .299 .646 & 26.592 .979 .646 & 28.084 .430 .000 \\
\hline Kota Langsa & 8.600 .083 .229 & 13.718 .522 .158 & 5.405 .424 .740 & 6.324 .574 .550 & 5.466 .681 .550 \\
\hline $\begin{array}{l}\text { Kota } \\
\text { Lhokseumawe }\end{array}$ & 9.664 .140 .000 & 15.639 .023 .500 & 4.826 .800 .000 & 5.089 .012 .952 & 4.252 .300 .000 \\
\hline Kota Sabang & 4.660 .582 .320 & 12.756 .226 .724 & 10.857 .983 .647 & 11.752 .676 .257 & 11.422 .106 .000 \\
\hline Kota Subussalam & 4.541 .565 .455 & 24.967 .061 .697 & 1.857 .600 .000 & 4.162 .600 .000 & 5.274 .100 .000 \\
\hline
\end{tabular}

Tabel 5

Realisasi Retribusi Daerah 2013-2017

\begin{tabular}{|l|c|c|c|c|c|}
\hline \multicolumn{1}{|c|}{ Kab/Kota } & $\mathbf{2 0 1 3}$ & $\mathbf{2 0 1 4}$ & $\mathbf{2 0 1 5}$ & $\mathbf{2 0 1 6}$ & $\mathbf{2 0 1 7}$ \\
\hline Aceh Barat & 19.242 .181 .321 & 67.004 .225 .338 & 13.529 .349 .330 & 6.859 .002 .548 & 5.233 .370 .064 \\
\hline Aceh Barat Daya & 3.668 .432 .570 & 1.939 .416 .282 & 3.391 .593 .542 & 2.914 .789 .910 & 2.433 .714 .502 \\
\hline Aceh Besar & 11.624 .888 .596 & 7.952 .497 .704 & 6.203 .391 .515 & 6.203 .391 .515 & 5.028 .668 .300 \\
\hline Aceh Jaya & 3.736 .283 .486 & 7.746 .821 .182 & 10.790 .738 .205 & 13.810 .237 .460 & 16.827 .463 .861 \\
\hline Aceh Singkil & 7.065 .923 .666 & 12.862 .473 .612 & 14.164 .078 .826 & 15.337 .071 .702 & 18.720 .739 .294 \\
\hline Simeulue & 6.634 .006 .880 & 1.272 .737 .773 & 1.882 .395 .729 & 1.603 .191 .065 & 1.918 .146 .131 \\
\hline Aceh Tamiang & 20.085 .268 .751 & 71.737 .834 .712 & 7.424 .803 .813 & 30.476 .102 .499 & 8.423 .362 .874 \\
\hline
\end{tabular}




\begin{tabular}{|l|c|c|c|c|c|}
\hline \multicolumn{1}{|c|}{ Kab/Kota } & $\mathbf{2 0 1 3}$ & $\mathbf{2 0 1 4}$ & $\mathbf{2 0 1 5}$ & $\mathbf{2 0 1 6}$ & $\mathbf{2 0 1 7}$ \\
\hline Aceh Tengah & 7.315 .624 .211 & 9.999 .224 .701 & 7.698 .231 .984 & 6.063 .907 .206 & 5.597 .836 .308 \\
\hline Aceh Tenggara & 15.045 .628 .269 & 35.330 .136 .876 & 31.037 .577 .159 & 1.194 .507 .553 & 881.390 .909 \\
\hline Aceh Timur & 8.368 .291 .093 & 21.145 .233 .035 & 30.101 .828 .434 & 36.753 .896 .260 & 17.846 .424 .206 \\
\hline Aceh Utara & 52.051 .629 .991 & 120.224 .580 .918 & 51.154 .239 .742 & 5.263 .672 .340 & 3.036 .594 .908 \\
\hline Bener Meriah & 8.318 .731 .292 & 7.534 .401 .660 & 5.198 .500 .907 & 3.914 .709 .882 & 4.725 .739 .000 \\
\hline Bireun & 12.580 .979 .610 & 8.697 .714 .630 & 14.862 .066 .190 & 13.510 .255 .196 & 10.899 .296 .091 \\
\hline Gayo Lues & 12.033 .978 .452 & 15.505 .329 .095 & 17.572 .094 .079 & 18.057 .685 .849 & 22.296 .472 .033 \\
\hline Nagan Raya & 1.574 .093 .193 & 10.947 .824 .162 & 3.278 .899 .609 & 2.779 .862 .954 & 1.801 .485 .225 \\
\hline Pidie & 11.589 .452 .822 & 13.212 .177 .037 & 16.638 .678 .529 & 22.589 .882 .478 & 27.439 .417 .965 \\
\hline Aceh selatan & 21.512 .528 .194 & 7.581 .543 .513 & 3.470 .577 .346 & 3.422 .532 .343 & 9.327 .679 .236 \\
\hline Pidie Jaya & 6.919 .806 .065 & 20.075 .705 .929 & 21.259 .626 .819 & 21.174 .988 .097 & 20.557 .200 .578 \\
\hline Kota Banda Aceh & 17.893 .186 .595 & 17.513 .331 .930 & 19.494 .630 .582 & 21.567 .480 .773 & 22.577 .269 .595 \\
\hline Kota Langsa & 5.206 .868 .353 & 12.800 .842 .081 & 4.349 .945 .627 & 4.563 .580 .383 & 4.501 .489 .952 \\
\hline $\begin{array}{l}\text { Kota } \\
\text { Lhokseumawe }\end{array}$ & 6.795 .080 .768 & 12.617 .519 .534 & 3.593 .498 .911 & 5.263 .672 .340 & 4.050 .483 .522 \\
\hline Kota Sabang & 4.775 .912 .035 & 10.045 .885 .885 & 12.045 .875 .639 & 11.772 .685 .948 & 14.319 .933 .071 \\
\hline Kota Subussalam & 2.893 .220 .485 & 18.450 .143 .032 & 1.608 .635 .927 & 1.862 .694 .256 & 2.603 .084 .216 \\
\hline
\end{tabular}

Tabel 6

Target Hasil Kekayaan Daerah yang Dipisahkan 2013-2017

\begin{tabular}{|l|c|c|c|c|c|}
\hline \multicolumn{1}{|c|}{ Kab/Kota } & $\mathbf{2 0 1 3}$ & $\mathbf{2 0 1 4}$ & $\mathbf{2 0 1 5}$ & $\mathbf{2 0 1 6}$ & $\mathbf{2 0 1 7}$ \\
\hline Aceh Barat & 3.375 .202 .713 & 3.375 .202 .713 & 3.459 .582 .781 & 4.785 .619 .099 & 4.816 .063 .499 \\
\hline Aceh Barat Daya & 850.000 .000 & 1.000 .000 .000 & 1.426 .824 .415 & 1.417 .802 .001 & 1.500 .000 .000 \\
\hline Aceh Besar & 1.800 .000 .000 & 2.200 .000 .000 & 2.700 .000 .000 & 2.700 .000 .000 & 3.500 .000 .000 \\
\hline Aceh Jaya & 3.890 .930 .000 & 4.085 .242 .163 & 5.560 .173 .049 & 5.955 .121 .530 & 6.431 .673 .688 \\
\hline Aceh Singkil & 1.600 .000 .000 & 1.750 .000 .000 & 2.400 .000 .000 & 2.742 .378 .665 & 2.878 .008 .000 \\
\hline Simeulue & 2.280 .000 .000 & 2.533 .417 .384 & 3.884 .302 .776 & 4.128 .118 .924 & 4.201 .523 .668 \\
\hline Aceh Tamiang & 2.484 .000 .000 & 2.890 .500 .356 & 5.264 .941 .292 & 6.364 .973 .098 & 6.364 .937 .098 \\
\hline Aceh Tengah & 2.600 .000 .000 & 3.050 .000 .000 & 4.949 .850 .248 & 5.299 .533 .368 & 5.150 .000 .000 \\
\hline Aceh Tenggara & 1.293 .295 .000 & 1.200 .000 .000 & 2.042 .446 .483 & 3.000 .000 .000 & 3.000 .000 .000 \\
\hline Aceh Timur & 2.181 .001 .764 & 1.665 .341 .224 & 2.262 .355 .357 & 2.200 .000 .000 & 2.200 .000 .000 \\
\hline Aceh Utara & 14.242 .726 .830 & 15.727 .284 .970 & 15.909 .687 .500 & 20.215 .822 .614 & 20.015 .000 .000 \\
\hline Bener Meriah & 2.563 .503 .039 & 2.800 .977 .861 & 3.978 .858 .954 & 4.899 .346 .646 & 4.500 .000 .000 \\
\hline Bireun & 3.000 .000 .000 & 3.700 .000 .000 & 4.869 .061 .663 & 4.869 .061 .663 & 4.950 .000 .000 \\
\hline Gayo Lues & 1.656 .781 .000 & 2.537 .319 .727 & 2.902 .882 .970 & 3.318 .806 .547 & 3.522 .603 .117 \\
\hline Nagan Raya & 1.050 .000 .000 & 1.700 .000 .000 & 7.460 .761 .984 & 3.000 .000 .000 & 5.500 .000 .000 \\
\hline Pidie & 1.300 .000 .000 & 1.479 .604 .400 & 1.679 .604 .400 & 2.583 .118 .716 & 3.101 .301 .120 \\
\hline Aceh selatan & 2.459 .195 .788 & 2.690 .273 .354 & 3.920 .190 .094 & 4.402 .490 .841 & 5.395 .995 .916 \\
\hline Pidie Jaya & 550.000 .000 & 1.004 .434 .000 & 1.557 .246 .472 & 1.794 .169 .348 & 2.000 .000 .000 \\
\hline Banda Aceh & 738.714 .350 & 560.000 .000 & 560.000 .000 & 800.000 .000 & 1.100 .000 .000 \\
\hline Langsa & 413.617 .460 & 391.835 .870 & 518.845 .242 & 518.845 .242 & 518.845 .242 \\
\hline Lhokseumawe & 2.865 .000 .000 & 3.040 .000 .000 & 4.040 .000 .000 & 20.215 .822 .614 & 5.040 .000 .000 \\
\hline Sabang & 1.469 .821 .765 & 1.607 .769 .400 & 1.823 .152 .766 & 1.823 .152 .765 & 1.923 .152 .765 \\
\hline Subussalam & 300.000 .000 & 300.000 .000 & 300.000 .000 & 620.795 .004 & 744.312 .268 \\
\hline
\end{tabular}

Tabel 7

Realisasi Hasil Kekayaan Daerah yang Dipisahkan 2013-2017

\begin{tabular}{|l|c|c|c|c|c|}
\hline \multicolumn{1}{|c|}{ Kab/Kota } & $\mathbf{2 0 1 3}$ & $\mathbf{2 0 1 4}$ & $\mathbf{2 0 1 5}$ & $\mathbf{2 0 1 6}$ & $\mathbf{2 0 1 7}$ \\
\hline Aceh Barat & 3.375 .202 .713 & 3.687 .870 .750 & 4.816 .071 .999 & 4.789 .619 .099 & 4.730 .000 .266 \\
\hline Aceh Barat Daya & 999.948 .015 & 1.092 .580 .016 & 1.426 .824 .415 & 2.914 .789 .910 & 1.364 .572 .493 \\
\hline
\end{tabular}




\begin{tabular}{|l|c|c|c|c|c|}
\hline \multicolumn{1}{|c|}{ Kab/Kota } & $\mathbf{2 0 1 3}$ & $\mathbf{2 0 1 4}$ & $\mathbf{2 0 1 5}$ & $\mathbf{2 0 1 6}$ & $\mathbf{2 0 1 7}$ \\
\hline Aceh Besar & 2.481 .482 .703 & 2.121 .335 .481 & 2.770 .298 .936 & 2.770 .289 .936 & 3.658 .841 .413 \\
\hline Aceh Jaya & 3.736 .283 .486 & 4.251 .129 .519 & 5.560 .173 .049 & 5.955 .121 .530 & 6.431 .673 .688 \\
\hline Aceh Singkil & 1.645 .369 .006 & 1.798 .389 .428 & 2.492 .589 .401 & 2.742 .378 .665 & 2.878 .007 .440 \\
\hline Simeulue & 2.533 .417 .384 & 2.769 .193 .606 & 3.938 .963 .007 & 4.128 .118 .924 & 4.201 .523 .668 \\
\hline Aceh Tamiang & 2.568 .443 .750 & 2.806 .500 .356 & 4.264 .941 .292 & 5.963 .629 .755 & 6.333 .551 .580 \\
\hline Aceh Tengah & 3.191 .889 .748 & 3.623 .266 .435 & 4.949 .850 .248 & 5.299 .533 .368 & 5.371 .551 .816 \\
\hline Aceh Tenggara & 3.012 .851 .979 & 1.333 .770 .606 & 2.042 .446 .483 & 2.940 .978 .715 & 2.392 .445 .407 \\
\hline Aceh Timur & 1.496 .403 .183 & 1.654 .233 .034 & 2.304 .355 .357 & 2.189 .314 .214 & 2.077 .375 .411 \\
\hline Aceh Utara & 14.242 .726 .830 & 15.571 .993 .311 & 20.223 .043 .958 & 20.095 .166 .364 & 19.340 .718 .610 \\
\hline Bener Meriah & 2.563 .503 .039 & 2.800 .977 .861 & 4.013 .054 .954 & 4.583 .932 .198 & 4.490 .684 .023 \\
\hline Bireun & 3.412 .338 .964 & 3.728 .447 .185 & 4.869 .061 .663 & 4.916 .471 .188 & 4.954 .350 .870 \\
\hline Gayo Lues & 2.415 .428 .208 & 2.368 .147 .237 & 2.946 .712 .970 & 3.318 .806 .547 & 3.522 .600 .617 \\
\hline Nagan Raya & 1.590 .826 .387 & 1.802 .961 .121 & 12.856 .335 .883 & 3.028 .940 .638 & 2.915 .223 .053 \\
\hline Pidie & 1.382 .939 .013 & 1.513 .655 .337 & 2.594 .226 .209 & 2.583 .118 .716 & 3.101 .301 .121 \\
\hline Aceh selatan & 2.459 .195 .788 & 2.690 .273 .354 & 3.920 .190 .094 & 4.402 .490 .841 & 5.395 .995 .916 \\
\hline Pidie Jaya & 783.520 .910 & 1.062 .374 .849 & 1.557 .246 .472 & 1.894 .169 .348 & 2.005 .224 .834 \\
\hline Banda Aceh & 738.714 .323 & 807.146 .467 & 1.054 .070 .428 & 1.047 .405 .108 & 1.008 .081 .651 \\
\hline Langsa & 363.617 .460 & 397.301 .824 & 518.845 .242 & 515.564 .364 & 604.966 .136 \\
\hline Lhokseumawe & 2.454 .417 .855 & 2.681 .787 .313 & 4.011 .810 .914 & 20.095 .166 .364 & 5.093 .717 .479 \\
\hline Sabang & 1.469 .821 .769 & 1.605 .981 .380 & 2.097 .286 .613 & 2.084 .024 .609 & 2.005 .782 .627 \\
\hline Subussalam & 272.713 .095 & 297.976 .368 & 389.133 .931 & 620.795 .994 & 744.312 .269 \\
\hline
\end{tabular}

Tabel 8

Target Pendapatan Asli Daerah yang Sah 2013-2017

\begin{tabular}{|l|c|c|c|c|c|}
\hline \multicolumn{1}{|c|}{ Kab/Kota } & $\mathbf{2 0 1 3}$ & $\mathbf{2 0 1 4}$ & $\mathbf{2 0 1 5}$ & $\mathbf{2 0 1 6}$ & $\mathbf{2 0 1 7}$ \\
\hline Aceh Barat & 4.796 .161 .200 & 12.965 .944 .666 & 83.294 .485 .810 & 84.243 .610 .050 & 130.996 .940 .407 \\
\hline Aceh Barat Daya & 26.850 .000 .000 & 45.622 .456 .500 & 48.933 .588 .669 & 69.138 .626 .728 & 89.124 .424 .373 \\
\hline Aceh Besar & 5.583 .000 .000 & 36.251 .107 .950 & 45.306 .103 .308 & 45.305 .103 .308 & 53.306 .653 .300 \\
\hline Aceh Jaya & 8.928 .292 .826 & 12.505 .219 .191 & 14.135 .393 .752 & 19.581 .057 .016 & 17.344 .875 .318 \\
\hline Aceh Singkil & 2.135 .649 .713 & 9.371 .182 .663 & 11.265 .142 .950 & 16.138 .246 .245 & 10.903 .879 .893 \\
\hline Simeulue & 2.158 .191 .000 & 26.454 .622 .063 & 29.344 .918 .000 & 35.345 .849 .609 & 46.556 .100 .099 \\
\hline Aceh Tamiang & 5.707 .764 .055 & 7.280 .086 .632 & 23.189 .439 .799 & 75.842 .374 .311 & 99.824 .981 .346 \\
\hline Aceh Tengah & 53.132 .939 .328 & 101.464 .147 .757 & 118.555 .866 .967 & 142.622 .168 .880 & 133.479 .154 .915 \\
\hline Aceh Tenggara & 1.293 .295 .000 & 11.491 .000 .000 & 32.185 .934 .000 & 41.247 .325 .300 & 5.160 .835 .398 \\
\hline Aceh Timur & 25.272 .692 .016 & 28.071 .000 .000 & 43.659 .395 .927 & 77.134 .853 .960 & 130.221 .691 .444 \\
\hline Aceh Utara & 18.806 .728 .725 & 20.872 .424 .000 & 133.618 .998 .042 & 371.567 .824 .565 & 196.959 .953 .071 \\
\hline Bener Meriah & 2.250 .370 .600 & 24.924 .707 .396 & 50.929 .019 .479 & 67.008 .332 .255 & 13.000 .000 .000 \\
\hline Bireun & 82.500 .000 .000 & 138.745 .846 .072 & 140.820 .222 .537 & 158.193 .018 .352 & 172.237 .800 .000 \\
\hline Gayo Lues & 3.887 .500 .000 & 5.740 .000 .000 & 10.497 .649 .000 & 12.579 .452 .897 & 25.742 .589 .628 \\
\hline Nagan Raya & 21.492 .211 .875 & 31.592 .211 .875 & 57.444 .456 .353 & 96.135 .855 .636 & 64.402 .026 .949 \\
\hline Pidie & 66.019 .746 .361 & 92.473 .040 .191 & 156.831 .347 .114 & 188.053 .074 .304 & 288.239 .563 .837 \\
\hline Aceh selatan & 8.999 .488 .740 & 53.098 .066 .228 & 70.301 .290 .675 & 91.491 .207 .651 & 118.584 .274 .768 \\
\hline Pidie Jaya & 622.000 .000 & 622.000 .000 & 14.147 .526 .343 & 12.514 .318 .000 & 15.930 .650 .455 \\
\hline Banda Aceh & 38.825 .555 .261 & 74.257 .511 .731 & 106.629 .860 .486 & 134.922 .409 .467 & 171.993 .101 .733 \\
\hline Langsa & 49.492 .656 .322 & 82.016 .525 .259 & 96.864 .174 .966 & 113.376 .755 .473 & 106.714 .977 .813 \\
\hline Lhokseumawe & 5.700 .000 .000 & 5.100 .000 .000 & 24.304 .708 .015 & 371.567 .824 .565 & 26.336 .132 .695 \\
\hline Sabang & 15.390 .286 .399 & 22.952 .011 .334 & 33.331 .400 .052 & 34.446 .973 .975 & 28.620 .185 .685 \\
\hline Subussalam & 859.998 .240 & 1.359 .998 .240 & 35.342 .796 .670 & 57.639 .959 .884 & 54.430 .362 .290 \\
\hline
\end{tabular}

Tabel 9 
Realisasi Pendapatan Asli Daerah yang Sah 2013-2017

\begin{tabular}{|l|c|c|c|c|c|}
\hline \multicolumn{1}{|c|}{ Kab/Kota } & $\mathbf{2 0 1 3}$ & $\mathbf{2 0 1 4}$ & $\mathbf{2 0 1 5}$ & $\mathbf{2 0 1 6}$ & $\mathbf{2 0 1 7}$ \\
\hline Aceh Barat & 5.471 .335 .567 & 19.132 .637 .135 & 85.118 .050 .251 & 100.137 .635 .612 & 110.509 .368 .471 \\
\hline Aceh Barat Daya & 20.862 .378 .996 & 49.640 .903 .317 & 48.896 .329 .648 & 64.997 .670 .437 & 77.397 .478 .547 \\
\hline Aceh Besar & 8.881 .185 .785 & 37.134 .083 .163 & 62.377 .266 .445 & 62.377 .266 .445 & 59.395 .577 .178 \\
\hline Aceh Jaya & 9.735 .065 .141 & 12.563 .511 .541 & 15.814 .257 .235 & 15.918 .136 .746 & 14.484 .135 .696 \\
\hline Aceh Singkil & 3.229 .609 .732 & 10.732 .581 .017 & 14.640 .912 .724 & 12.498 .345 .278 & 8.837 .495 .935 \\
\hline Simeulue & 1.140 .280 .153 & 26.242 .770 .421 & 34.738 .608 .930 & 33.847 .741 .612 & 42.481 .066 .368 \\
\hline Aceh Tamiang & 7.847 .890 .528 & 10.793 .648 .436 & 71.490 .531 .630 & 58.089 .793 .007 & 80.193 .707 .826 \\
\hline Aceh Tengah & 62.062 .207 .901 & 97.998 .797 .618 & 134.770 .631 .745 & 117.356 .405 .379 & 125.042 .760 .687 \\
\hline Aceh Tenggara & 3.012 .851 .979 & 9.821 .442 .088 & 14.788 .534 .546 & 41.264 .461 .668 & 5.920 .853 .693 \\
\hline Aceh Timur & 3.389 .134 .672 & 50.130 .384 .918 & 54.718 .068 .050 & 43.391 .198 .403 & 124.239 .391 .515 \\
\hline Aceh Utara & 14.475 .625 .186 & 16.578 .162 .167 & 102.769 .333 .582 & 329.638 .426 .257 & 140.718 .983 .673 \\
\hline Bener Meriah & 788.188 .342 & 24.200 .788 .649 & 46.278 .991 .223 & 52.782 .260 .211 & 8.452 .964 .495 \\
\hline Bireun & 5.198 .554 .711 & 146.000 .868 .535 & 136.593 .247 .568 & 147.139 .101 .042 & 154.124 .601 .115 \\
\hline Gayo Lues & 2.789 .505 .879 & 3.835 .343 .658 & 12.270 .202 .592 & 14.255 .927 .352 & 24.837 .347 .073 \\
\hline Nagan Raya & 25.412 .964 .981 & 38.142 .136 .832 & 47.142 .350 .393 & 71.469 .296 .971 & 42.322 .839 .445 \\
\hline Pidie & 53.750 .773 .374 & 136.510 .203 .662 & 172.165 .580 .516 & 181.716 .282 .510 & 213.285 .340 .006 \\
\hline Aceh selatan & 5.181 .753 .325 & 57.480 .251 .367 & 68.566 .013 .270 & 91.115 .920 .170 & 105.628 .786 .011 \\
\hline Pidie Jaya & 1.194 .226 .564 & 1.825 .357 .796 & 15.745 .103 .337 & 13.440 .441 .860 & 15.341 .343 .709 \\
\hline Banda Aceh & 49.355 .278 .394 & 86.919 .972 .924 & 115.814 .569 .009 & 148.044 .256 .918 & 160.691 .888 .125 \\
\hline Langsa & 45.562 .752 .929 & 89.488 .036 .240 & 91.704 .324 .970 & 103.129 .419 .521 & 98.823 .761 .794 \\
\hline Lhokseumawe & 4.692 .447 .132 & 6.743 .065 .887 & 18.940 .022 .804 & 329.638 .426 .257 & 26.002 .294 .619 \\
\hline Sabang & 15.992 .806 .171 & 24.110 .693 .130 & 27.299 .152 .987 & 25.823 .616 .816 & 30.184 .060 .674 \\
\hline Subussalam & 1.041 .327 .425 & 1.105 .686 .570 & 26.615 .452 .362 & 32.063 .357 .242 & 44.637 .230 .591 \\
\hline
\end{tabular}

Tabel 10

Realisasi Pendapatan Asli Daerah 2013-2017

\begin{tabular}{|l|c|c|c|c|c|}
\hline \multicolumn{1}{|c|}{ Kab/Kota } & PAD 2013 & PAD 2014 & PAD 2015 & PAD 2016 & PAD 2017 \\
\hline Aceh Barat & 46.928 .106 .803 & 112.034 .104 .121 & 130.428 .452 .038 & 140.614 .479 .580 & 91.571 .494 .831 \\
\hline Aceh Barat Daya & 32.534 .985 .971 & 58.384 .755 .218 & 61.190 .085 .187 & 80.496 .803 .924 & 161.742 .858 .644 \\
\hline Aceh Besar & 76.107 .259 .036 & 114.542 .978 .639 & 140.533 .050 .822 & 140.533 .050 .822 & 145.464 .468 .479 \\
\hline Aceh Jaya & 20.646 .749 .350 & 36.406 .713 .759 & 40.385 .794 .989 & 45.774 .374 .212 & 52.599 .500 .274 \\
\hline Aceh Singkil & 18.024 .823 .053 & 31.030 .277 .202 & 39.375 .695 .217 & 42.057 .160 .523 & 43.441 .129 .848 \\
\hline Simeulue & 15.309 .778 .448 & 34.956 .712 .854 & 45.938 .231 .973 & 48.646 .141 .736 & 61.095 .183 .851 \\
\hline Aceh Tamiang & 42.592 .561 .280 & 97.374 .583 .496 & 100.454 .203 .157 & 114.051 .092 .364 & 116.246 .212 .754 \\
\hline Aceh Tengah & 76.870 .446 .782 & 132.068 .284 .863 & 157.256 .773 .343 & 156.911 .299 .656 & 163.000 .739 .413 \\
\hline Aceh Tenggara & 25.620 .560 .182 & 56.043 .722 .466 & 59.153 .235 .036 & 61.475 .042 .351 & 60.053 .234 .222 \\
\hline Aceh Timur & 42.805 .235 .988 & 86.544 .530 .935 & 98.704 .908 .418 & 94.337 .443 .632 & 158.492 .371 .450 \\
\hline Aceh Utara & 99.869 .693 .144 & 178.550 .865 .626 & 194.029 .636 .826 & 388.251 .800 .973 & 202.091 .566 .055 \\
\hline Bener Meriah & 18.918 .704 .154 & 44.090 .831 .965 & 58.753 .978 .243 & 66.454 .059 .145 & 82.038 .407 .024 \\
\hline Bireun & 93.893 .140 .984 & 172.302 .227 .983 & 173.972 .782 .734 & 186.162 .575 .752 & 192.939 .858 .236 \\
\hline Gayo Lues & 20.213 .909 .299 & 28.906 .170 .978 & 41.407 .502 .305 & 46.277 .349 .072 & 60.312 .455 .602 \\
\hline Nagan Raya & 37.942 .005 .578 & 65.177 .801 .946 & 79.938 .395 .296 & 104.202 .917 .807 & 74.051 .054 .127 \\
\hline Pidie & 76.878 .689 .101 & 166.598 .720 .923 & 210.501 .782 .065 & 249.489 .453 .846 & 267.608 .101 .034 \\
\hline Aceh selatan & 36.181 .171 .785 & 78.487 .063 .289 & 92.665 .502 .126 & 125.989 .165 .879 & 140.875 .267 .832 \\
\hline Pidie Jaya & 14.052 .583 .435 & 29.851 .341 .064 & 44.573 .668 .037 & 45.986 .243 .650 & 47.409 .466 .485 \\
\hline Banda Aceh & 129.122 .120 .462 & 171.777 .275 .449 & 209.914 .107 .301 & 258.591 .409 .670 & 270.170 .805 .366 \\
\hline Langsa & 57.243 .381 .960 & 114.168 .702 .058 & 109.116 .860 .676 & 121.369 .467 .376 & 120.138 .956 .032 \\
\hline Lhokseumawe & 36.213 .933 .082 & 48.730 .219 .320 & 56.560 .454 .282 & 388.251 .800 .973 & 62.986 .260 .104 \\
\hline Sabang & 27.377 .339 .120 & 42.723 .293 .975 & 49.602 .766 .629 & 47.776 .631 .105 & 55.081 .057 .066 \\
\hline
\end{tabular}


Tabel 11

Analisis Efektivitas Pajak Daerah

\begin{tabular}{|c|c|c|c|c|c|}
\hline Kab/Kota & 2013 & 2014 & 2015 & 2016 & 2017 \\
\hline Aceh Barat & Sangat Efektif & Sangat Efektif & Efektif & Tidak Efektif & Sangat Efektif \\
\hline Aceh Barat Daya & Tidak Efektif & Tidak Efektif & Efektif & Sangat Efektif & Sangat Efektif \\
\hline Aceh Besar & Sangat Efektif & Sangat Efektif & Sangat Efektif & Sangat Efektif & Sangat Efektif \\
\hline Aceh Jaya & Sangat Efektif & Sangat Efektif & Sangat Efektif & Cukup Efektif & Sangat Efektif \\
\hline Aceh Singkil & Sangat Efektif & Kurang Efektif & Kurang Efektif & Cukup Efektif & Cukup Efektif \\
\hline Simeulue & Sangat Efektif & Sangat Efektif & Sangat Efektif & Sangat Efektif & Sangat Efektif \\
\hline Aceh Tamiang & Sangat Efektif & Cukup Efektif & Kurang Efektif & Kurang Efektif & Kurang Efektif \\
\hline Aceh Tengah & Sangat Efektif & Sangat Efektif & Sangat Efektif & Sangat Efektif & Sangat Efektif \\
\hline Aceh Tenggara & Sangat Efektif & Cukup Efektif & Sangat Efektif & Sangat Efektif & Kurang Efektif \\
\hline Aceh Timur & Sangat Efektif & Sangat Efektif & Sangat Efektif & Sangat Efektif & Sangat Efektif \\
\hline Aceh Utara & Cukup Efektif & Cukup Efektif & Efektif & Cukup Efektif & Sangat Efektif \\
\hline Bener Meriah & Sangat Efektif & Sangat Efektif & Sangat Efektif & Kurang Efektif & Cukup Efektif \\
\hline Bireun & Sangat Efektif & Sangat Efektif & Sangat Efektif & Cukup Efektif & Sangat Efektif \\
\hline Gayo Lues & Sangat Efektif & Sangat Efektif & Sangat Efektif & Sangat Efektif & Sangat Efektif \\
\hline Nagan Raya & Cukup Efektif & Sangat Efektif & Cukup Efektif & Tidak Efektif & Cukup Efektif \\
\hline Pidie & Sangat Efektif & Sangat Efektif & Sangat Efektif & Sangat Efektif & Sangat Efektif \\
\hline Aceh selatan & Efektif & Sangat Efektif & Sangat Efektif & Sangat Efektif & Sangat Efektif \\
\hline Pidie Jaya & Kurang Efektif & Sangat Efektif & Sangat Efektif & Sangat Efektif & Sangat Efektif \\
\hline Banda Aceh & Sangat Efektif & Sangat Efektif & Sangat Efektif & Sangat Efektif & Sangat Efektif \\
\hline Langsa & Sangat Efektif & Sangat Efektif & Sangat Efektif & Efektif & Sangat Efektif \\
\hline Lhokseumawe & Sangat Efektif & Sangat Efektif & Kurang Efektif & Cukup Efektif & Efektif \\
\hline Sabang & Sangat Efektif & Sangat Efektif & Sangat Efektif & Sangat Efektif & Sangat Efektif \\
\hline Subussalam & Kurang Efektif & Kurang Efektif & Kurang Efektif & Kurang Efektif & Cukup Efektif \\
\hline
\end{tabular}

Tabel 12

Analisis Efektivitas Retribusi Daerah

\begin{tabular}{|l|l|l|l|l|l|}
\hline \multicolumn{1}{|c|}{ Kab/Kota } & \multicolumn{1}{c|}{$\mathbf{2 0 1 3}$} & \multicolumn{2}{c|}{$\mathbf{2 0 1 4}$} & \multicolumn{2}{c|}{$\mathbf{2 0 1 5}$} \\
\hline Aceh Barat & Kurang Efektif & Kurang Efektif & Kurang Efektif & Kurang Efektif & Tidak Efektif \\
\hline Aceh Barat Daya & Tidak Efektif & Tidak Efektif & Kurang Efektif & Kurang Efektif & Tidak Efektif \\
\hline Aceh Besar & Cukup Efektif & Efektif & Efektif & Efektif & Kurang Efektif \\
\hline Aceh Jaya & Kurang Efektif & Kurang Efektif & Kurang Efektif & Kurang Efektif & Kurang Efektif \\
\hline Aceh Singkil & Kurang Efektif & Kurang Efektif & Kurang Efektif & Kurang Efektif & Kurang Efektif \\
\hline Simeulue & Kurang Efektif & Kurang Efektif & Efektif & Cukup Efektif & Efektif \\
\hline Aceh Tamiang & Kurang Efektif & Efektif & Sangat Efektif & Efektif & Kurang Efektif \\
\hline Aceh Tengah & Tidak Efektif & Kurang Efektif & Kurang Efektif & Tidak Efektif & Tidak Efektif \\
\hline Aceh Tenggara & Kurang Efektif & Sangat Efektif & Sangat Efektif & Tidak Efektif & Tidak Efektif \\
\hline Aceh Timur & Kurang Efektif & Tidak Efektif & Kurang Efektif & Sangat Efektif & Cukup Efektif \\
\hline Aceh Utara & Kurang Efektif & Efektif & Sangat Efektif & Sangat Efektif & Cukup Efektif \\
\hline Bener Meriah & Tidak Efektif & Tidak Efektif & Cukup Efektif & Tidak Efektif & Kurang Efektif \\
\hline Bireun & Kurang Efektif & Sangat Efektif & Sangat Efektif & Efektif & Cukup Efektif \\
\hline
\end{tabular}




\begin{tabular}{|l|l|l|l|l|l|}
\hline \multicolumn{1}{|c|}{ Kab/Kota } & \multicolumn{1}{c|}{$\mathbf{2 0 1 3}$} & \multicolumn{1}{c|}{$\mathbf{2 0 1 4}$} & \multicolumn{1}{c|}{$\mathbf{2 0 1 5}$} & \multicolumn{1}{c|}{$\mathbf{2 0 1 7}$} \\
\hline Gayo Lues & Efektif & Kurang Efektif & Efektif & Efektif & Cukup Efektif \\
\hline Nagan Raya & Tidak Efektif & Tidak Efektif & Tidak Efektif & Tidak Efektif & Tidak Efektif \\
\hline Pidie & Kurang Efektif & Tidak Efektif & Sangat Efektif & Cukup Efektif & Kurang Efektif \\
\hline Aceh selatan & Cukup Efektif & Cukup Efektif & Kurang Efektif & Sangat Efektif & Sangat Efektif \\
\hline Pidie Jaya & Tidak Efektif & Cukup Efektif & Kurang Efektif & Kurang Efektif & Kurang Efektif \\
\hline Banda Aceh & Sangat Efektif & Kurang Efektif & Kurang Efektif & Cukup Efektif & Kurang Efektif \\
\hline Langsa & Tidak Efektif & Efektif & Kurang Efektif & Kurang Efektif & Cukup Efektif \\
\hline Lhokseumawe & Kurang Efektif & Kurang Efektif & Kurang Efektif & Sangat Efektif & Efektif \\
\hline Sabang & Sangat Efektif & Kurang Efektif & Sangat Efektif & Sangat Efektif & Sangat Efektif \\
\hline Subussalam & Kurang Efektif & Kurang Efektif & Cukup Efektif & Tidak Efektif & Tidak Efektif \\
\hline
\end{tabular}

Tabel 13

Analisis Efektivitas Hasil Kekayaan Daerah yang Dipisahkan

\begin{tabular}{|c|c|c|c|c|c|}
\hline Kab/Kota & 2013 & 2014 & 2015 & 2016 & 2017 \\
\hline Aceh Barat & Efektif & Sangat Efektif & Sangat Efektif & Sangat Efektif & Efektif \\
\hline Aceh Barat Daya & Sangat Efektif & Sangat Efektif & Efektif & Sangat Efektif & Cukup Efektif \\
\hline Aceh Besar & Sangat Efektif & Efektif & Sangat Efektif & Sangat Efektif & Sangat Efektif \\
\hline Aceh Jaya & Efektif & Sangat Efektif & Efektif & Efektif & Efektif \\
\hline Aceh Singkil & Sangat Efektif & Sangat Efektif & Sangat Efektif & Efektif & Efektif \\
\hline Simeulue & Sangat Efektif & Sangat Efektif & Sangat Efektif & Efektif & Sangat Efektif \\
\hline Aceh Tamiang & Sangat Efektif & Efektif & Cukup Efektif & Efektif & Efektif \\
\hline Aceh Tengah & Sangat Efektif & Sangat Efektif & Efektif & Efektif & Sangat Efektif \\
\hline Aceh Tenggara & Sangat Efektif & Sangat Efektif & Efektif & Efektif & Kurang Efektif \\
\hline Aceh Timur & Kurang Efektif & Efektif & Sangat Efektif & Efektif & Efektif \\
\hline Aceh Utara & Efektif & Efektif & Sangat Efektif & Efektif & Efektif \\
\hline Bener Meriah & Efektif & Efektif & Sangat Efektif & Efektif & Efektif \\
\hline Bireun & Sangat Efektif & Sangat Efektif & Efektif & Sangat Efektif & Sangat Efektif \\
\hline Gayo Lues & Sangat Efektif & Efektif & Sangat Efektif & Efektif & Efektif \\
\hline Nagan Raya & Sangat Efektif & Sangat Efektif & Sangat Efektif & Sangat Efektif & Tidak Efektif \\
\hline Pidie & Sangat Efektif & Sangat Efektif & Sangat Efektif & Efektif & Sangat Efektif \\
\hline Aceh selatan & Efektif & Efektif & Efektif & Efektif & Efektif \\
\hline Pidie Jaya & Sangat Efektif & Sangat Efektif & Efektif & Sangat Efektif & Sangat Efektif \\
\hline Banda Aceh & Efektif & Sangat Efektif & Sangat Efektif & Sangat Efektif & Efektif \\
\hline Langsa & Cukup Efektif & Sangat Efektif & Efektif & Efektif & Sangat Efektif \\
\hline Lhokseumawe & Cukup Efektif & Cukup Efektif & Efektif & Efektif & Sangat Efektif \\
\hline Sabang & Sangat Efektif & Efektif & Sangat Efektif & Sangat Efektif & Sangat Efektif \\
\hline Subussalam & Cukup Efektif & Efektif & Sangat Efektif & Sangat Efektif & Sangat Efektif \\
\hline
\end{tabular}

Tabel 14

Analisis Efektivitas Lain-lain PAD yang Sah

\begin{tabular}{|l|c|c|c|c|c|}
\hline \multicolumn{1}{|c|}{ Kab/Kota } & $\mathbf{2 0 1 3}$ & $\mathbf{2 0 1 4}$ & $\mathbf{2 0 1 5}$ & $\mathbf{2 0 1 6}$ & $\mathbf{2 0 1 7}$ \\
\hline Aceh Barat & Sangat Efektif & Sangat Efektif & PanSangat Efektif & Sangat Efektif & Cukup Efektif \\
\hline Aceh Barat Daya & Kurang Efektif & Sangat Efektif & Efektif & Efektif & Cukup Efektif \\
\hline Aceh Besar & Sangat Efektif & Sangat Efektif & Sangat Efektif & Sangat Efektif & Sangat Efektif \\
\hline Aceh Jaya & Sangat Efektif & Sangat Efektif & Sangat Efektif & Cukup Efektif & Cukup Efektif \\
\hline
\end{tabular}




\begin{tabular}{|l|c|c|c|c|c|}
\hline \multicolumn{1}{|c|}{ Kab/Kota } & $\mathbf{2 0 1 3}$ & $\mathbf{2 0 1 4}$ & $\mathbf{2 0 1 5}$ & $\mathbf{2 0 1 6}$ & $\mathbf{2 0 1 7}$ \\
\hline Aceh Singkil & Sangat Efektif & Sangat Efektif & Sangat Efektif & Kurang Efektif & Cukup Efektif \\
\hline Simeulue & Tidak Efektif & Efektif & Sangat Efektif & Efektif & Efektif \\
\hline Aceh Tamiang & Sangat Efektif & Sangat Efektif & Sangat Efektif & Kurang Efektif & Kurang Efektif \\
\hline Aceh Tengah & Sangat Efektif & Efektif & Sangat Efektif & Cukup Efektif & Efektif \\
\hline Aceh Tenggara & Sangat Efektif & Cukup Efektif & Tidak Efektif & Sangat Efektif & Sangat Efektif \\
\hline Aceh Timur & Tidak Efektif & Sangat Efektif & Sangat Efektif & Tidak Efektif & Efektif \\
\hline Aceh Utara & Kurang Efektif & Kurang Efektif & Kurang Efektif & Cukup Efektif & Kurang Efektif \\
\hline Bener Meriah & Tidak Efektif & Efektif & Cukup Efektif & Kurang Efektif & Kurang Efektif \\
\hline Bireun & Tidak Efektif & Sangat Efektif & Efektif & Efektif & Cukup Efektif \\
\hline Gayo Lues & Kurang Efektif & KurangEfektif & Sangat Efektif & Sangat Efektif & Efektif \\
\hline Nagan Raya & Sangat Efektif & Sangat Efektif & Cukup Efektif & Kurang Efektif & Kurang Efektif \\
\hline Pidie & Cukup Efektif & Sangat Efektif & Sangat Efektif & Efektif & Kurang Efektif \\
\hline Aceh selatan & Tidak Efektif & Sangat Efektif & Efektif & Efektif & Cukup Efektif \\
\hline Pidie Jaya & Sangat Efektif & Sangat Efektif & Sangat Efektif & Sangat Efektif & Efektif \\
\hline Banda Aceh & Sangat Efektif & Sangat Efektif & Sangat Efektif & Sangat Efektif & Efektif \\
\hline Langsa & Efektif & Sangat Efektif & Efektif & Cukup Efektif & Efektif \\
\hline Lhokseumawe & Cukup Efektif & Sangat Efektif & Kurang Efektif & Cukup Efektif & Efektif \\
\hline Sabang & Sangat Efektif & Sangat Efektif & Cukup Efektif & Kurang Efektif & Sangat Efektif \\
\hline Subussalam & Kurang Efektif & Cukup Efektif & Kurang Efektif & Tidak Efektif & Cukup Efektif \\
\hline
\end{tabular}

Tabel 15

Analisis Kontribusi Pajak Daerah

\begin{tabular}{|c|c|c|c|c|c|}
\hline Kab/Kota & 2013 & 2014 & 2015 & 2016 & 2017 \\
\hline Aceh Barat & Sedang & Kurang & Kurang & Kurang & Cukup Baik \\
\hline Aceh Barat Daya & Sangat Kurang & Sangat Kurang & Sangat Kurang & Kurang & Sangat Kurang \\
\hline Aceh Besar & Sangat Baik & Baik & Cukup Baik & Cukup Baik & Baik \\
\hline Aceh Jaya & Kurang & Sedang & Sangat Kurang & Sangat Kurang & Kurang \\
\hline Aceh Singkil & Sedang & Kurang & Kurang & Kurang & Kurang \\
\hline Simeulue & Sedang & Sangat Kurang & Sangat Kurang & Kurang & Kurang \\
\hline Aceh Tamiang & Sedang & Sangat Kurang & Sangat Kurang & Sangat Kurang & Sangat Kurang \\
\hline Aceh Tengah & Sangat Kurang & Sangat Kurang & Sangat Kurang & Sangat Kurang & Sangat Kurang \\
\hline Aceh Tenggara & Kurang & Kurang & Kurang & Kurang & Kurang \\
\hline Aceh Timur & Kurang & Sangat Kurang & Sangat Kurang & Sangat Kurang & Sangat Kurang \\
\hline Aceh Utara & Kurang & Kurang & Kurang & Sangat Kurang & Kurang \\
\hline Bener Meriah & Sangat Kurang & Sangat Kurang & Sangat Kurang & Sangat Kurang & Sangat Kurang \\
\hline Bireun & Kurang & Sangat Kurang & Kurang & Sangat Kurang & Kurang \\
\hline Gayo Lues & Kurang & Kurang & Kurang & Kurang & Sangat Kurang \\
\hline Nagan Raya & Kurang & Kurang & Kurang & Kurang & Sedang \\
\hline Pidie & Kurang & Sangat Kurang & Sangat Kurang & Kurang & Sangat Kurang \\
\hline Aceh selatan & Kurang & Sangat Kurang & Kurang & Kurang & Kurang \\
\hline Pidie Jaya & Sedang & Kurang & Kurang & Kurang & Kurang \\
\hline Banda Aceh & Cukup Baik & Cukup Baik & Sedang & Sedang & Sedang \\
\hline Langsa & Kurang & Sangat Kurang & Sangat Kurang & Sangat Kurang & Kurang \\
\hline Lhokseumawe & Baik & Baik & Cukup Baik & Sangat Kurang & Baik \\
\hline Sabang & Kurang & Kurang & Kurang & Kurang & Kurang \\
\hline Subussalam & Cukup Baik & Kurang & Kurang & Kurang & Kurang \\
\hline
\end{tabular}

Tabel 16

Analisis Kontribusi Retribusi Daerah

.




\begin{tabular}{|c|c|c|c|c|c|}
\hline Kab/Kota & 2013 & 2014 & 2015 & 2016 & 2017 \\
\hline Aceh Barat & Baik & Sangat Baik & Kurang & Sangat Kurang & Sangat Kurang \\
\hline Aceh Barat Daya & Kurang & Sangat Kurang & Sangat Kurang & Sangat Kurang & Sangat Kurang \\
\hline Aceh Besar & Kurang & Sangat Kurang & Sangat Kurang & Sangat Kurang & Sangat Kurang \\
\hline Aceh Jaya & Kurang & Sedang & Sedang & Cukup Baik & Cukup Baik \\
\hline Aceh Singkil & Cukup Baik & Baik & Cukup Baik & Cukup Baik & Baik \\
\hline Simeulue & Baik & Sangat Kurang & Sangat Kurang & Sangat Kurang & Sangat Kurang \\
\hline Aceh Tamiang & Baik & Sangat Baik & Sangat Kurang & Sedang & Sangat Kurang \\
\hline Aceh Tengah & Sangat Kurang & Sangat Kurang & Sangat Kurang & Sangat Kurang & Sangat Kurang \\
\hline Aceh Tenggara & Sangat Baik & Sangat Baik & Sangat Baik & Sangat Kurang & Sangat Kurang \\
\hline Aceh Timur & Kurang & Sedang & Cukup Baik & Cukup Baik & Kurang \\
\hline Aceh Utara & Sangat Baik & Sangat Baik & Sedang & Sangat Kurang & Sangat Kurang \\
\hline Bener Meriah & Baik & Kurang & Sangat Kurang & Sangat Kurang & Sangat Kurang \\
\hline Bireun & Kurang & Sangat Kurang & Sangat Kurang & Sangat Kurang & Sangat Kurang \\
\hline Gayo Lues & Sangat Baik & Sangat Baik & Baik & Cukup Baik & Cukup Baik \\
\hline Nagan Raya & Sangat Kurang & Kurang & Sangat Kurang & Sangat Kurang & Sangat Kurang \\
\hline Pidie & Kurang & Sangat Kurang & Sangat Kurang & Sangat Kurang & Kurang \\
\hline Aceh selatan & Sangat Baik & Sangat Kurang & Sangat Kurang & Sangat Kurang & Sangat Kurang \\
\hline Pidie Jaya & Baik & Sangat Baik & Baik & Baik & Baik \\
\hline Kota Banda Aceh & Kurang & Kurang & Sangat Kurang & Sangat Kurang & Sangat Kurang \\
\hline Kota Langsa & Sangat Kurang & Kurang & Sangat Kurang & Sangat Kurang & Sangat Kurang \\
\hline $\begin{array}{l}\text { Kota } \\
\text { Lhokseumawe }\end{array}$ & Kurang & Sedang & Sangat Kurang & Sangat Kurang & Sangat Kurang \\
\hline Kota Sabang & Kurang & Sedang & Sedang & Sedang & Sedang \\
\hline Kota Subussalam & Cukup Baik & Sangat Baik & Sangat Kurang & Sangat Kurang & Sangat Kurang \\
\hline
\end{tabular}

Tabel 17

Analisis Kontribusi Hasil Kekayaan Daerah yang Dipisahkan

\begin{tabular}{|c|c|c|c|c|c|}
\hline Kab/Kota & 2013 & 2014 & 2015 & 2016 & 2017 \\
\hline Aceh Barat & Sangat Kurang & Sangat Kurang & Sangat Kurang & Sangat Kurang & Sangat Kurang \\
\hline Aceh Barat Daya & Sangat Kurang & Sangat Kurang & Sangat Kurang & Sangat Kurang & Sangat Kurang \\
\hline Aceh Besar & Sangat Kurang & Sangat Kurang & Sangat Kurang & Sangat Kurang & Sangat Kurang \\
\hline Aceh Jaya & Kurang & Kurang & Kurang & Kurang & Kurang \\
\hline Aceh Singkil & Sangat Kurang & Sangat Kurang & Sangat Kurang & Sangat Kurang & Sangat Kurang \\
\hline Simeulue & Kurang & Sangat Kurang & Sangat Kurang & Sangat Kurang & Sangat Kurang \\
\hline Aceh Tamiang & Sangat Kurang & Sangat Kurang & Sangat Kurang & Sangat Kurang & Sangat Kurang \\
\hline Aceh Tengah & Sangat Kurang & Sangat Kurang & Sangat Kurang & Sangat Kurang & Sangat Kurang \\
\hline Aceh Tenggara & Kurang & Sangat Kurang & Sangat Kurang & Sangat Kurang & Sangat Kurang \\
\hline Aceh Timur & Sangat Kurang & Sangat Kurang & Sangat Kurang & Sangat Kurang & Sangat Kurang \\
\hline Aceh Utara & Kurang & Sangat Kurang & Kurang & Sangat Kurang & Sangat Kurang \\
\hline Bener Meriah & Kurang & Sangat Kurang & Sangat Kurang & Sangat Kurang & Sangat Kurang \\
\hline Bireun & Sangat Kurang & Sangat Kurang & Sangat Kurang & Sangat Kurang & Sangat Kurang \\
\hline Gayo Lues & Kurang & Sangat Kurang & Sangat Kurang & Sangat Kurang & Sangat Kurang \\
\hline Nagan Raya & Sangat Kurang & Sangat Kurang & Kurang & Sangat Kurang & Sangat Kurang \\
\hline Pidie & Sangat Kurang & Sangat Kurang & Sangat Kurang & Sangat Kurang & Sangat Kurang \\
\hline Aceh selatan & Sangat Kurang & Sangat Kurang & Sangat Kurang & Sangat Kurang & Sangat Kurang \\
\hline Pidie Jaya & Sangat Kurang & Sangat Kurang & Sangat Kurang & Sangat Kurang & Sangat Kurang \\
\hline Banda Aceh & Sangat Kurang & Sangat Kurang & Sangat Kurang & Sangat Kurang & Sangat Kurang \\
\hline Langsa & Sangat Kurang & Sangat Kurang & Sangat Kurang & Sangat Kurang & Sangat Kurang \\
\hline Lhokseumawe & Sangat Kurang & Sangat Kurang & Sangat Kurang & Sangat Kurang & Sangat Kurang \\
\hline Sabang & Sangat Kurang & Sangat Kurang & Sangat Kurang & Sangat Kurang & Sangat Kurang \\
\hline
\end{tabular}




\begin{tabular}{|l|c|c|c|c|c|}
\hline Subussalam & Sangat Kurang & Sangat Kurang & Sangat Kurang & Sangat Kurang & Sangat Kurang \\
\hline
\end{tabular}

Tabel 18

Analisis Kontribusi Lain-lain PAD yang sah

\begin{tabular}{|c|c|c|c|c|c|}
\hline Kab/Kota & 2013 & 2014 & 2015 & 2016 & 2017 \\
\hline Aceh Barat & Kurang & Kurang & Sangat Baik & Sangat Baik & Sangat Baik \\
\hline Aceh Barat Daya & Sangat Baik & Sangat Baik & Sangat Baik & Sangat Baik & Sangat Baik \\
\hline Aceh Besar & Kurang & Cukup Baik & Baik & Baik & Baik \\
\hline Aceh Jaya & Baik & Cukup Baik & Cukup Baik & Cukup Baik & Sedang \\
\hline Aceh Singkil & Kurang & Cukup Baik & Cukup Baik & Sedang & Sedang \\
\hline Simeulue & Sangat Kurang & Sangat Baik & Sangat Baik & Sangat Baik & Sangat Baik \\
\hline Aceh Tamiang & Kurang & Kurang & Sangat Baik & Sangat Baik & Sangat Baik \\
\hline Aceh Tengah & Sangat Baik & Sangat Baik & Sangat Baik & Sangat Baik & Sangat Baik \\
\hline Aceh Tenggara & Kurang & Kurang & Sedang & Sangat Baik & Sangat Kurang \\
\hline Aceh Timur & Sangat Kurang & Sangat Baik & Sangat Baik & Baik & Sangat Baik \\
\hline Aceh Utara & Kurang & Sangat Kurang & Sangat Baik & Sangat Baik & Sangat Baik \\
\hline Bener Meriah & Sangat Kurang & Sangat Baik & Sangat Baik & Sangat Baik & Kurang \\
\hline Bireun & Sangat Kurang & Sangat Baik & Sangat Baik & Sangat Baik & Sangat Baik \\
\hline Gayo Lues & Sangat Kurang & Kurang & Sedang & Cukup Baik & Baik \\
\hline Nagan Raya & Sangat Baik & Sangat Baik & Sangat Baik & Sangat Baik & Sangat Baik \\
\hline Pidie & Sangat Baik & Sangat Baik & Sangat Baik & Sangat Baik & Sangat Baik \\
\hline Aceh selatan & Kurang & Sangat Baik & Sangat Baik & Sangat Baik & Sangat Baik \\
\hline Pidie Jaya & Sangat Kurang & Sangat Kurang & Cukup Baik & Sedang & Cukup Baik \\
\hline Banda Aceh & Cukup Baik & Sangat Baik & Sangat Baik & Sangat Baik & Sangat Baik \\
\hline Langsa & Sangat Baik & Sangat Baik & Sangat Baik & Sangat Baik & Sangat Baik \\
\hline Lhokseumawe & Kurang & Kurang & Cukup Baik & Sangat Baik & Baik \\
\hline Sabang & Sangat Baik & Sangat Baik & Sangat Baik & Sangat Baik & Sangat Baik \\
\hline Subussalam & Sangat Kurang & Sangat Kurang & Sangat Baik & Sangat Baik & Sangat Baik \\
\hline
\end{tabular}

\section{Kesimpulan, Keterbatasan dan Saran \\ Kesimpulan}

1. Tingkat efektivitas pajak daerah rata-rata setiap tahun (2013-2017) dikategorikan 89,91\% (cukup efektif), artinya pemerintah daerah mampu merealisasikan penerimaan pajak dengan sangat baik.

2. Tingkat efektivitas retribusi daerah rata-rata dari tahun 2013-2017 dikategorikan kurang efektif yaitu sebesar $77,87 \%$, salah satu faktornya adalah terdapat beberapa daerah dalam penentuan target retribusi yang terlalu besar sedangkan penerimaannya tidak sebanding dengan anggaran yang dibuat.

3. Tingkat efektivitas hasil kekayaan daerah yang dipisahkan rata-rata penerimaan (2013-2017) sebesar $107,06 \%$ artinya sangat efektif, dimana setiap kabupaten/kota mampu merealisasikan penerimaannya dengan target yang telah ditetapkan.
4. Tingkat efektivitas pendapatan asli daerah yang sah rata-rata sebesar 102,06\% dengan kriteria sangat efektif.

5. Tingkat kontribusi pajak daerah terhadap PAD dari tahun 2013-2017 kategori kurang dengan persentase sebesar $15,15 \%$, dimana kontribusi pajak daerah jika dibandingkan dengan penerimaan PAD masih tergolong rendah, inilah yang menjadi tugas pemerintah daerah agar dapat meningkatkannya dengan cara meningkatkan kesadaran untuk membayar pajak.

6. Tingkat kontribusi retribusi daerah terhadap PAD sebesar 20,46\% dengan kategori sedang.

7. Tingkat kontribusi hasil kekayaan daerah yang dipisahkan rata-rata penerimaan terhadap pendapatan asli daerah sebesar 4,89\% kategori sangat kurang, artinya penerimaan dari komponen ini tidak sebanding dengan jumlah Pendapatan Asli Daerah yang besar.

8. Tingkat kontribusi pendapatan asli daerah yang sah rata-rata penerimaan dari tahun 2013-2017 
sebesar 50,64 kategori sangat baik, dimana untuk penerimaan pendapatan asli daerah yang sah menujukkan nilai yang besar terhadap pendapatan asli daerah. Artinya pendapatan asli daerah yang sah sangat berkontribusi untuk pendapatan asli daerah kabupaten/kota.

\section{Keterbatasan}

Penelitian ini memiliki keterbatasan yang memerlukan pengembangan dalam penelitianpenelitian selanjutnya. Adapun keterbatasan dalam penelitian ini antara lain:

1. Data penelitian ini hanya menggunakan data sekunder dari BPKA (Badan Pengelolaan Keuangan Aceh), sebaiknya ditambah dengan data primer seperti wawancara.

2. Penelitian ini tidak menghitung analisis efisiensi komponen PAD, sebaiknya ditambahkan sehingga mendapatkan hasil analisa lebih sempurna.

3. Penelitian ini hanya menggunakan kurun waktu yang pendek yaitu lima tahun sebaiknya ditambahkan enam atau tujuh tahun.

\section{Saran}

Sehubungan dengan hasil penelitian yang diperoleh, dan adanya keterbatasan dalam penelitian ini, maka dapat ditemukan beberapa saran sebagai berikut :

1. Bagi pemerintah diharapkan dapat menggali lagi sumber-sumber penerimaan Pendapatan Asli Daerah.

2. Pemerintah juga harus melakukan sosialiasi pentingnya membayar pajak kepada masyarakat agar meningkatkan kesadaran masyarakat untuk meningkatkan penerimaan daerah.

3. Bagi pemerintah daerah seharusnya dapat melihat potensi daerah dalam hal penentuan target anggaran supaya nantinya realisasi penerimaan tidak jauh berbeda dengan target yang ditetapkan.

4. Bagi peneliti selanjutnya dapat menambahkan analisis efesiensi untuk menghitung komponen PAD agar tidak hanya membahas efektivitas dan kontribusi saja.

\section{Daftar Pustaka}

Asnariza, Abubakar Hamzah, N. S. (2014). Analisis Efesiensi dan Efektivitas Pemungutan
Pendapatan Asli Daerah Kota Sabang. Jurnal Ilmu Ekonomi Pascasarjana Universitas Syiah Kuala, 2(4), 77-85.

Danied Mikha. (2010). Analisis Kontribusi Pajak Dan Retribusi Daerah Terhadap Pendapatan Asli Daerah Kabupaten Sleman. Jurnal Emba, 1, 122.

Fauziah Isfatul, et all. (2014). Analisis Kontribusi Penerimaan Pajak Daerah Sebagai Salah Satu Sumber Pendapatan Asli Daerah (Pad) Kabupaten Malang, 8(33), 44.

Halim, Abdul. 2004. Akuntansi Keuangan Daerah. Jakarta. Penerbit Salemba Empat

2008. Akuntansi sektor Publik Akuntansi Keuangan Daerah. Jakarta. Penerbit Salemba Empat

Halim \& Kusufi. 2013. Akuntansi sektor Publik. Jakarta. Penerbit Salemba Empat

Handoko, S. (2013). Analisis Tingkat Efektivitas Pajak Daerah Sebagai Sumber Pendapatan Asli Daerah Kota Pontianak.

Keputusan Menteri Dalam Negeri No. 690900327. 1996. tentang Pedoman Penilaian dan Kinerja Keuangan. Jakarta.

Qanun Aceh. Nomor 11 Tahun 2017 tentang Perubahan Atas Qanun Aceh Nomor 2 Tahun 2012 Pajak Aceh

Republik Indonesia. Undang-Undang Nomor 34 Tahun 2000 tentangPajak Daerah dan Retribusi Daerah.

Undang-Undang Nomor 28 Tahun 2009 tentangPajak Daerah dan Retribusi Daerah.

Sekaran, Uma dan Roger Bougie. (2017). Metode Penelitian untuk Bisnis Pendekatan Pengembangan-Keahlian. Edisi 6. Buku 2. Jakarta: Salemba Empat.

Sayangbati, A. (2016). Analisis Kontribusi Dan Trend Penerimaan Pajak Daerah, Retribusi Daerah Pada Pendapatan Asli Daerah Studi Pada Kabupaten Minahasa Utara Periode Tahun ( 2007-2013 ) in Local Revenue Study in Kabupaten Minahasa Utara S Period of, 16(03), 699-707. 